\title{
The Influence of Nitric Oxid Donors Nebivolol and S-Nitrosoglutathion of the Oxidatives Stress and Liver Function in Rats
}

\author{
BEATRICE ROZALINA BUCA ${ }^{1}$, LILIANA MITITELU-TARTAU ${ }^{1 *}$, CRISTIANA FILIP1, NINA FILIP1, CIPRIAN REZUS ${ }^{1}$, \\ CRISTINA IANCU ${ }^{2}$, ELENA REZUS ${ }^{1}$, ALIN CONSTANTIN PINZARIU ${ }^{1}$, SORIN AURELIAN PASCA ${ }^{3}$, CATALINA ELENA LUPUSORU', \\ RAOUL VASILE LUPUSORU ${ }^{1}$ \\ ${ }^{1}$ Grigore T. Popa University of Medicine and Pharmacy, Faculty of Medicine, 16 Universitatii Str, 700115, lasi , Romania \\ ${ }^{2}$ Grigore T Popa University of Medicine and Pharmacy, Faculty of Pharmacy, 16 Universitatii Str, 700115, Iasi , Romania \\ ${ }^{3}$ Ion Ionescu de la Brad University of Agricultural and Veterinary Medicine lasi, 3 Mihail Sadoveanu Alley, 700490, Iasi, Romania
}

\begin{abstract}
We aimed to investigate the influence of two nitric oxide donors on the oxidative stress and the liver function in rats with experimental-induced acute paw inflammation. The experiment was carried out on white male Wistar rats (200-250 g), randomly assigned into 4 groups of 5 animals each, which received the substances intraperitoneal, as follows: group 1 (Control) saline solution $0.1 \mathrm{ml} / 100 \mathrm{~g}$ body weight; group 2 (IND) indomethacin $150 \mathrm{mg} / \mathrm{kg}$ body weight (kbw); groups 3(NEB) and 4(GSNO) nebivolol $1 \mathrm{mg} / \mathrm{kbw}$, respectively $\mathrm{S}$-nitroso-glutathione $1 \mathrm{mg} / \mathrm{kbw}$. Carrageenan-induced rat's paw edema test was used for the generation of acute inflammation. The activity of liver enzymes and of some antioxidant parameters was evaluated before the carrageenan injection, after 24 hours and 3 days. The experimental protocol was approved by the University's Ethic Committee on Research and Ethical Issues. The administration of indomethacin, nebivolol and S-nitroso-glutathione appears to decrease the oxidative stress after $24 \mathrm{~h}$ in rats with experimentalinduced acute paw inflammation. The nitric oxide donors nebivolol and S-nitroso-glutathione produced moderate functional and structural liver disturbances in rats with acute inflammation.
\end{abstract}

Keywords: Nebivolol, S-nitrosoglutathione, liver, oxidative stress, rats

Nitric oxide (NO), a molecule naturally produced in the body, has a complex chemistry and various biological actions. This mediator, synthesized in a series of cells from L-arginine, by the contribution of NO synthase (NOS), acts as an autocrine and paracrine signaling system at the molecular level, its sphere of influence occurring at a distance of about $100 \mathrm{im}$ from the source of production $[1,2]$. NO and its derivatives play key roles in the physiology and pathophysiology of the liver. Despite its diverse and complex actions, certain patterns of NO influence, on the pathogenesis and progression of liver diseases, have been revealed [3]. In general, NO generated by the endothelial NOS (eNOS) in sinusoidal endothelial hepatic cells, is protective against the damages, whereas the inducible NOS (iNOS)-derived NO is involved in the development and evolution of the local pathological processes $[4,5]$. Small amounts of NO, constantly produced by the eNOS in the liver, are essential in the modulation of local inflammatory processes and for the control of vascular tone and of the sinusoidal blood flow $[3,6]$. It, also preserves the integrity of hepatic stellate and of the latent Kupffer cells $[7,8]$, being involved in the maintaining of the liver homeostasis [9]

In various pathological states, the eNOS activity decreases, concomitantly with the up-regulation of iNOS. The accumulation of pro-inflammatory mediators and bacterial endotoxins stimulates the inducible isoform, to generate high quantities of $\mathrm{NO}$, which accentuate the liver injury. The decreasing in the NO production from the endothelial hepatic cells, causes the capillarisation of sinusoid vessels, activation, contraction and proliferation of hepatic stellate cells, which is accompanied by the deposition of extracellular matrix, and finally, by an increase in intrahepatic resistance and the disruption of the sinusoidal blood flow [3].

This investigation was undertaken with an objective to estimate the influence of two NO donors (nebivolol and S- nitroso-glutathione) on the liver function and the oxidative stress in laboratory animals with experimental-induced acute paw inflammation.

\section{Experimental part \\ Material and method}

White male Wistar rats (200-250 g) from the bio-base of the Grigore T. Popa from lasi University of Medicine and Pharmacy were used in the study. The animals were acclimatized three days before the experiment, under controlled environment of constant temperature $\left(23 \pm 2^{\circ} \mathrm{C}\right)$, relative humidity $(60 \pm 10 \%)$ and light /dark alternating regimen (lights on from 7 a.m. to 7 p.m.). The rats were fed with standard pellets and received water ad libitum, except during the investigation. To prevent the chronobiological interferences, the experimental research was performed between 8-14 a.m.

Nebivolol, S-nitroso-glutathione, carrageenan and saline were purchased from Sigma-Aldrich Chemical Co, Germany. The substances were extemporaneously dissolved in saline solution and heated to $36.7^{\circ} \mathrm{C}$ before the administration.

The experiments were conducted following the recommendation of the Ethic Committee on Research and Ethical Issues of our University, in accordance with the guidelines of the EU Directive 2010/63/EU, regarding the handling of laboratory animals $[10,11]$.

For the study, the animals were randomly allocated into 4 groups of 5 rats each, treated intraperitoneal, as follows: group 1 (Control) received saline solution $0.1 \mathrm{~mL} / 100 \mathrm{~g}$ body weight; group 2 (IND) received indomethacin 150 $\mathrm{mg} / \mathrm{kg}$ body weight ( $\mathrm{kbw}$ ); groups 3 (NEB) and 4 (GSNO) received nebivolol $1 \mathrm{mg} / \mathrm{kbw}$, respectively S-nitrosoglutathione $1 \mathrm{mg} / \mathrm{kbw}$. Indomethacin (IND) (a methylated indole derivative from the acetic acid group of the nonsteroidal anti-inflammatory drugs) was used as a positive control substance, with demonstrated anti-inflammatory 
activity in this experimental model of acute inflammation in rats $[12,13]$.

Acute local edema was induced by the subcutaneous administration of $0.2 \mathrm{~mL}$ carrageenan $1 \%$ diluted in saline, into the plantar zone of the rat's hind paw. This model is a standard experimental test, used to investigate the antiinflammatory activity of pharmacological active substances, evaluating their effects according to the capacity of preventing or reducing the local acute inflammatory process of the rat's paw $[14,15]$. The subplantar injection of carrageenan induces a biphasic response, consisting of an acute sw elling, with a maximal intensity after $3 \mathrm{~h}$ and lasting $6 \mathrm{~h}$ after the irritant agent administration, followed by a tardive reaction phase, with a highest inflammatory reaction after $72 \mathrm{~h}$, which progressively decline to $96 \mathrm{~h}$ [16-18].

The influence of the NO donors on the cell oxidative processes and the liver functionality was assessed by evaluating the biochemical profile, the activity of some antioxidant parameters and the histopathological liver modifications, in rats with acute inflammation. For biochemical analysis, blood samples $(2 \mathrm{~mL})$ were obtained from the retro-orbital plexus at baseline, just before the carrageenan injection (moment zero), and then, after $24 \mathrm{~h}$ and 3 days, in the experiment, to assess the activity of alanine aminotransferase (ALT), aspartate aminotransferase (AST) and lactate dehydrogenase (LDH). Serum biochemistry determinations were carried out using an ACCENT 200 analyzer. The effects of the tested NO donors on the oxidative stress, was evaluated by spectrophotometric measurement of the superoxide dismutase (SOD) and glutathione peroxidase (GPX) activity.

After $72 \mathrm{~h}$, the animals were euthanized under general anesthesia with $2 \%$ enflurane and the hepatic tissue fragments were taken for histopathological examination. The liver fragments were fixed in $10 \%$ formaldehyde solution, included in paraffin wax and subsequently sectioned into $5 \mu \mathrm{m}$ slices, using a laser microtome. The samples stained with Masson's trichrome method were examined by optical microscopy, using a Nikon E600 Ti Eclipse apparatus. With a digital camera, multiple images were taken and, thereafter were stored on the computer. Data were presented as mean \pm standard deviation (S.D.), and subjected to descriptive statistics, using the SPSS version 17.0 followed by the ANOVA one-way method. Significant difference was considered at the probability level, coefficient $p$ below 0.05 .

\section{Results and discussions}

In our experimental conditions, the sub-plantar injection of $1 \%$ carrageenan induced a progressive edema reaching its maximum after $4 h$, being maintained during $24 h$, and gradually decreased to $72 \mathrm{~h}$.

The biochemical investigations revealed that the administration of IND resulted in an increase of the ALT values in blood after $24 \mathrm{~h}$, statistically significant $(\diamond \bullet<0.01$ ) compared to baseline (fig. 1). The use of IND was associated with the intensification of AST activity, with high significance, compared to baseline after $24 \mathrm{~h}$ $(\diamond p<0.05)$, as well as $72 \mathrm{~h} \bullet p<0.01$ ) (fig. 2).

Drug-induced hepatotoxicity is a common source of liver injury, with a large variety of manifestations of different degree of severity, leading to acute hepatic failure. Literature data shows clinically significant hepatotoxicity associated with the use of non-steroidal anti-inflammatory drugs, including included ibuprofen, piroxicam, meloxicam, diclofenac naproxen, and IND [19]. Various

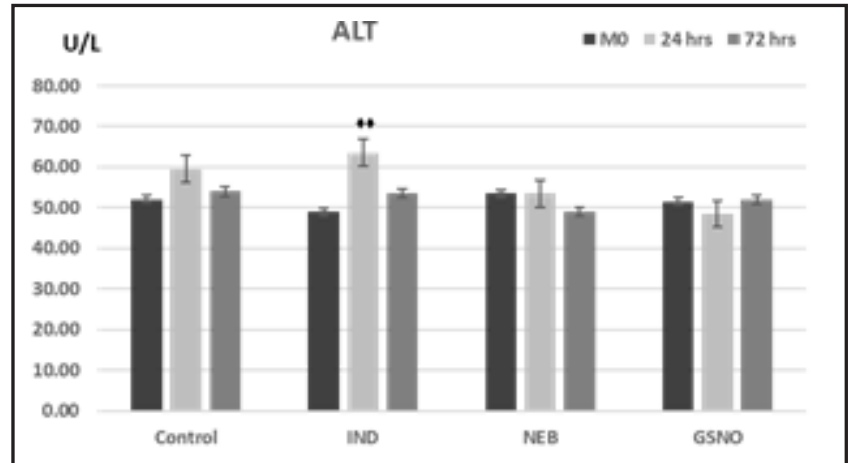

Fig. 1. The effects of NEB and GSNO on the ALT levels (U/L). Data were expressed as arithmetic mean \pm S.D. of mean for 5 animals in a group. $\bullet p<0.01$ significant vs M0.

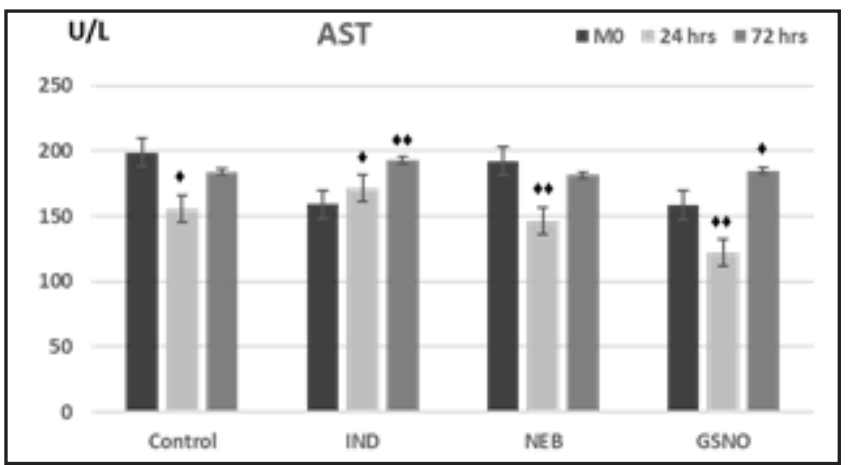

Fig. 2. The effects of NEB and GSNO on the AST levels (U/L). Data were expressed as arithmetic mean \pm S.D. of mean for 5 animals in a group. $\bullet<0.05, \diamond p<0.01$ significant vs M0

clinical trials reveals moderate and temporary ALT elevations (three times more than the upper limit of normal), cholestatic modifications, liver severe disturbances and structural alterations, during the treatment with IND, especially in patients with pre-existing chronic liver diseases. The mechanism responsible for the IND-induced liver damage is not completely deciphered, but is likely due to the impairment of the cytochrome P450 enzyme activity, or possible to the involvement of a toxic intermediate metabolite of it [20].

The treatment with GSNO elevated the plasma levels of AST statistically significant $(\diamond \bullet p<0.01)$ compared to baseline, $72 \mathrm{~h}$ after the induction of acute paw inflammation with carrageenan (fig. 2). All of the tested substances induced an amplification of LDH activity after $72 \mathrm{~h}$ in the experiment (fig. 3).

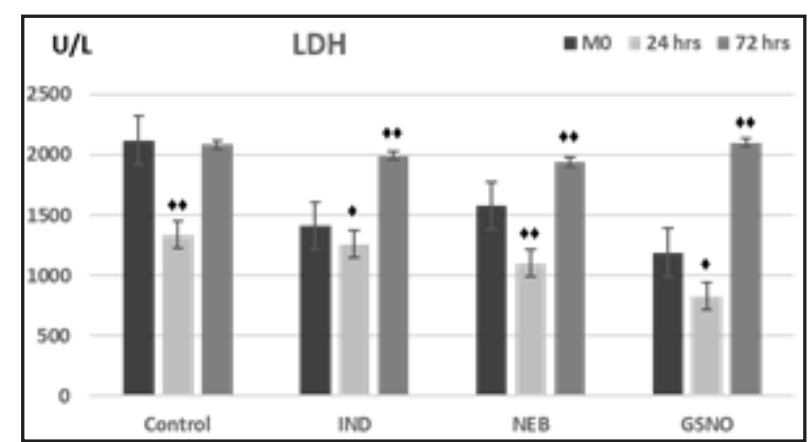

Fig. 3. The effects of NEB and GSNO on the LDH levels (U/L). Data were expressed as arithmetic mean \pm S.D. of mean for 5 animals in a group. $\bullet p<0.05, \diamond \bullet p<0.01$ significant vs M0

Literature data shows that NO plays an important role in the homeostasis of the liver, and its production is involved in both cytoprotection and cytotoxicity processes [3]. Experimental data reveals that NO appears to be beneficial for the hepatocytes having cytoprotective effects against 
inflammation and the direct tissue damage, but also the cytotoxic effects on the invading microorganisms and the tumor cells [21]. Several experimental studies demonstrated that NO exerts cytoprotective actions, as a response to the direct inflammatory and toxic aggression, as well as cytotoxic activity against some microorganisms and the tumor invasion $[22,23]$.

NO has different effects on the liver, according to the source from which it originated. In general, the eNOSderived NO is protective against the liver diseases, while iNOS-derived NO has damaging action, because it acts primarily as a pro-inflammatory mediator [24-26].

Some authors proved that the use of the NO donor, sodium nitroprusside was associated with an increase in the serum ALT, AST, total bilirubin values and the enhancement of the liver injury, in bile duct ligation model in mice [27].

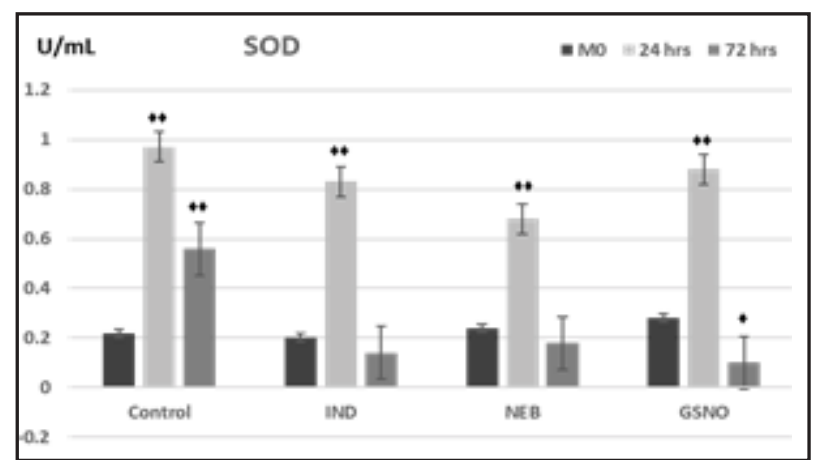

Fig. 4. The effects of NEB and GSNO on the activity of SOD $(\mathrm{U} / \mathrm{mL})$.

Data were expressed as arithmetic mean \pm S.D. of mean for 5

animals in a group. $\diamond p<0.05, \diamond p<0.01$ significant vs M0.

The use of IND, NEB and GSNO produced a marked elevation ( $f \& f \& p<0.01$ ) in SOD and GPx values after $24 \mathrm{~h}$, compared to the moment zero of the experiment (fig. 4, fig. 5). The administration of IND was accompanied by a considerable intensification ( $\bullet p<0.01$ ) in the GPxactivity after $72 \mathrm{~h}$ compared to the beginning of the experiment, in the acute paw inflammation test in rats (fig. 4). The treatment with GSNO induced a substantial increase $(\diamond p<0.05)$ in the serum levels of GPx after $72 \mathrm{~h}$ in the experiment (fig. 5).

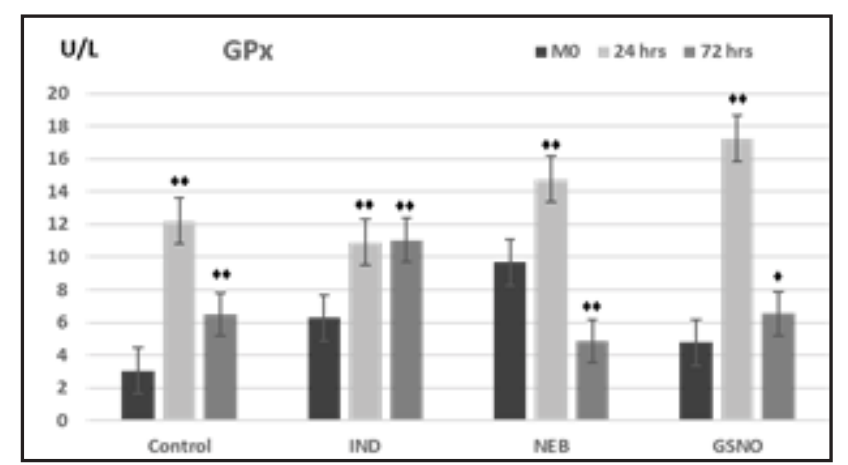

Fig. 5. The effects of NEB and GSNO on the activity of GPx (U/L). Data were expressed as arithmetic mean \pm S.D. of mean for 5 animals in a group. $\bullet p<0.05, \diamond p<0.01$ significant vs M0

Several antioxidants, such SOD are important operators with essential role in the control of nitro-oxidative stress. Recently, it has been suggested that the glycoprotein relaxin is involved in restoration of hepatic sinusoidal endothelial cell function. It up-regulates the eNOS in sinusoidal endothelial cells through the Kruppel-like transcription factor 2 (KLF2) and converts the activated liver stellate cells in the latent form. Relaxin also rises the levels of NO and decreases the intrahepatic portal pressure, due to the up-regulation of the relaxin receptor, only with predilection at the hepatic stellate cells in fibrotic liver [28]. Different researches reveal the involvement of NO in the inhibition of oxidative destruction and lipid peroxidation in different animal models of alcoholic and non-alcoholic (induced by acetaminophen or carbon tetrachloride) hepatic damages [29-31].

In the group of rats, which received saline, no substantial changes of the normal liver structure were found (fig. 6A). In the animals treated with IND, the histopathological examination have revealed the following changes in the liver architecture: toxic degeneration of the hepatocytes with alteration of their structure and accumulation of lipid deposits. The liver toxic effect is noted by severe degeneration of hepatocytes with heavily granular cytoplasm, the presence of intracytoplasmic lipid vacuoles, cariolisis (a clear sign of apoptosis), disappearance of nuclei, the activation and proliferation of the Kupffer cells (fig. 6B). In the group treated with NEB, the following pathological modifications in the liver configuration were noted: moderate to severe toxic hepatocytes injuries and the presence of the inflammatory reaction. The hepatocytes are altered, appear swollen and have a disintegrated or granular cytoplasm, hypertrophic nuclei and cariolisis (with the disappearance of the cell nucleus). The inflammatory component is objectified by the presence of numerous activated Kupffer cells (fig. 6C).

The treatment with GSNO was associated with the presence of the following histopathological liver alterations: moderate toxic degeneration with the disruption of the hepatocytes architecture (necrosis, cariolisis) and a mild hepatic inflammatory reaction (with activation of the Kupffer cells) (fig. 6D).
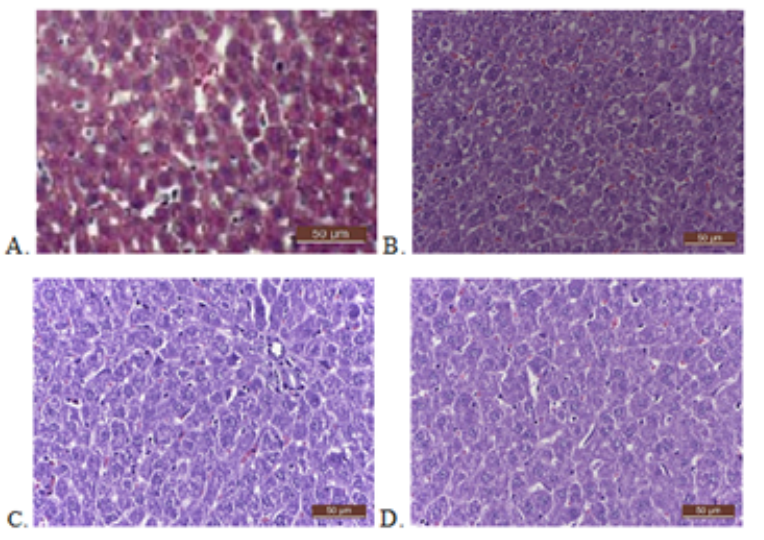

Fig. 6. The effects of the saline (A.), IND (B.), NEB (C.) and GSNO (D.) on liver structure (Masson's trichrome stain)

\section{Conclusions}

The administration of IND was accompanied by the functional and structural hepatic alteration in rats with acute paw inflammation. The treatment with IND, NEB and GSNO appears to decrease the oxidative stress after 24 hin this acute model of acute inflammation. The NO donors, NEB and GSNO induced moderate disruption of the liver architecture in carrageenan paw inflammation test in rats.

\section{References}

1.HILL, B.G., DRANKA, B.P., BAILEY, S.M., LANCASTER, J.R. JR, DARLEY-USMAR, V.M., J. Biol. Chem., 285, 2010, p. 19699.

2.VILLANUEVA, C., GIULIVI, C., Free Radic. Biol. Med., 49(3), 2010, p. 307.

3.IWAKIRI, Y., KIM, M.Y., Trends Pharmacol. Sci., 36(8), 2015, p. 524. 4.ABU-AMARA, M., YANG, S.Y., SEIFALIAN, A., DAVIDSON, B., FULLER, B., Liver Int., 32(4), 2012, p. 531. 
5.ATAKISI, E., MERHAN, O., Poisoning from specific toxic agents to novel rapid and simplified techniques for analysis, Malangu N. Ed., IntechOpen, Chapter 11, 2017, p. 197.

6.MAHMOUD, M.F., ZAKARIA, S., FAHMY, A., Adv. Pharmacol. Sci., Article ID 298792, 2015, p. 1.

7.TERASAKI, Y., AKUTA, T., TERASAKI, M., SAWA, T., MORI, T., OKAMOTO, T., OZAKI, M., TAKEYA, M., AKAIKE, T., Am. J. Respir. Crit. Care Med., 174(6): 2006, p. 665.

8.TATEYA, S., RIZZO, N.O., HANDA, P., CHENG, A.M., MORGANSTEVENSON, M., DAUM, G., CLOWES, A.W., MORTON, G.J ., SCHWARTZ, M.W., KIM, F., Diabetes, 60, 2011, p. 2792.

9.CARNOVALE, C.E., RONCO, M.T., Ann. Hepatol., 11(5): 2012, p. 636. 10.ANDERSEN, M.I., WINTER, L.M.F., An. Acad. Bras. Cienc., 2017, p. 1.

11.FESTING, S., WILKINSON, R., EMBO Rep., 8(6), 2007, p. 526.

12.DMOUR, R., MITITELU-TARTAU, L., SINDILAR, A., PASCA, S.A., NEDELCU, A.H., CRAUCIUC, D.V., DROCHIOI, C.I., HALIGA, R.E., HILITANU, L., PINZARIU, A.C., COBZARU, R.G., LUPUSORU, C.E., LUPUSORU, R.V., Rev. Chim. (Bucharest), 69, no. 7, 2018, p. 1744. 13.BUCA, B.R., MITITELU-TARTAU, L., REZUS, C., FILIP, C., PINZARIU, A.C., REZUS, E., POPA, G.E., PANAINTE, A., LUPUSORU, C.E., BOGDAN, M., PAVEL, L., LUPUSORU, R.V., Rev. Chim. (Bucharest), 69, no. 10, 2018, p. 2899.

14.CHOPADE, A.R., SAYYAD, F.J., NAIKWADE, N.S., Pharmacol. Rep., 66, 2014, p. 353.

15.POSADAS, I., BUCCI, M., ROVIEZZO, F., ROSSI, A., PARENTE, L., SAUTEBIN, L., CIRINO, G., Br. J. Pharmacol., 142(2), 2004, p. 331.

16.NECAS, J., BARTOSIKOVA, L., Vet. Med. (Praha), 58(4), 2013, p. 187. 17.DUARTE, D.B., VASKO, M.R., FEHRENBACHER, J.C., Curr. Protoc. Pharmacol, 72, 2016, p. 5.6.1

18.KOKSAL, M., OZKAN, I., YARIM, M., BILGE, S.S., BOZKURT, A., EROL, D.D., Rev. Chim (Bucharest), 62, no. 11, 2011, p. 1069.
19.SRIUTTHA, P., SIRICHANCHUEN, B., PERMSUWAN, U., Int. J. Hepatol., 2018, 2018, 5253623.

20.MASUBUCHI, Y., ENOKI, K., HORIE, T., Drug Metab. Dispos., 36(3), 2008, p. 597.

21.PERSICO, M., MASARONE, M., DAMATO, A., AMBROSIO, M., FEDERICO, A., ROSATO, V., BUCCI, T., CARRIZZO, A., VECCHIONE, C., BMC Gastroenterol., 17(1), 2017, p. 35.

22.TOMASIAN, D., KEANEY, J.F., VITA, J.A., Cardiovasc. Res., 47(3), 2000, p. 426.

23.CHOUDHARI, S.K., CHAUDHARY, M., BAGDE, S., GADBAIL, A.R., JOSHI, V., World J. Surg. Oncol., 11, 2013, p. 118.

24.CAI, Z., LU, Q., DING, Y., WANG, Q., XIAO, L., SONG, P., ZOU, M.H., Arterioscler. Thromb. Vasc. Biol., 35(11), 2015, p. 2366.

25.STANIMIROVIC, J., OBRADOVIC, M., ZAFIROVIC, S., BOGDANOVIC, N., GLUVIC, Z., MOUSA, S.A., ISENOVIC, E.R., Clin. Lipidol., 10(2), 2015, p. 167.

26.ZHANG, Y.Q., DING, N., ZENG, Y.F., XIANG, Y.Y., YANG, M.W., HONG, F.F., YANG, S.L., World J. Gastroenterol., 23(14), 2017, p. 2505.

27.VAN THUY, T.T., THUY, L.T., YOSHIZATO, K., KAWADA, N., Sci. Rep., 7, 2017, p. 41888.

28.FALLOWFIELD, J .A., HAYDEN, A.L., SNOWDON, V.K., AUCOTT, R.L., STUTCHFIELD, B.M., MOLE, D.J., PELLICORO, A., GORDON-WALKER, T.T., HENKE, A., SCHRADER, J., TRIVEDI, P.J ., PRINCIVALLE, M., FORBES, S.J ., COLLINS, J.E., IREDALE, J.P., Hepatology, 59, 2014, p. 1492.

29.PAROLA, M., ROBINO, G, J. Hepatol., 35(2), 2001, p. 297.

30.LIU, J., LI, C., WAALKES, M.P., CLARK, J., MYERS, P., SAAVEDRA, J.E., KEEFER, L.K., Hepatology, 37(2), 2003, p. 324.

31.PINZARIU, AC, OBOROCEANU, T, ELOAE, FZ; HRISTOV, I, COSTAN, VV, LABUSCA, L, CIANGA, P, VERESTIUC, L, HANGANU, B, CRAUCIUC, DV, MANOILESCU, IS, SINDILAR, E, MOCANU, V, Rev. Chim. (Bucharest), 69, no. 3, 2018, p. 731-734

Manuscript received: 13.08 .2018 